\title{
Characteristics, Extraction, Purification, and the Recent Applications of Sesame Oil in Food Products
}

\author{
Vira Putri Yarlina ${ }^{1}$, Edy Subroto ${ }^{2}$, Aldila Din Pangawikan ${ }^{3}$, Amanah Sobarina $^{4}$ \\ Department of Food Industrial Technology, Faculty of Agro-Industrial Technology, Universitas Padjadjaran \\ Jalan Raya Bandung-Sumedang Km. 21, Jatinangor, Sumedang 40600, Indonesia. \\ vira.putri.yarlina@unpad.ac.id, 2edy.subroto@unpad.ac.id, 3pangawikan@unpad.ac.id, \\ ${ }^{4}$ amanahsobarina@gmail.com
}

\begin{abstract}
Sesame Oil derived from sesame seeds (Sesamum indicum L.) is commonly formed as edible oil, seasoning, salad oil, butter, mayonnaise, and many other applications. The review aims to provide information on sesame oil which includes physical properties (rheology, density, thermal characteristics, optical characteristics), chemical properties (acid value, saponification value, iodine number, peroxide value, and antioxidants), extraction, purification, as well as various current applications of sesame seeds in the application product. Sesame oil has the advantages, namely containing sesamolin which can be converted to sesamol which shows higher antioxidant activity and stability than other vegetable oils. Sesame oils can be used for the production of mayonnaise, oleogel, cocoa cream, and various fatbased food products.
\end{abstract}

Key words: Sesame oil; physicochemical; Purification; mayonnaise, oleogel, cocoa cream

\section{INTRODUCTION}

Sesame (Sesamum indicum L.) is a type of plantation commodity with great potential. Sesame commodity has high economic value and is multipurpose. In the economic sector, sesame tends to be better appointed as a trade commodity between countries, where the need for sesame is increasing, one of which is sesame oil [1]. Sesame seeds have grown almost in Asia and Africa because widely grown in the subtropical and tropical climate.

The oil derived from sesame seeds are commonly used as edible oil, seasoning, or salad oil [2]. The oil content of sesame seeds are 44.6-53.1\%. Sesame oil has rich $36.12-43.63 \%$ oleic acid as monounsaturated fatty acid and $39.13-46.38 \%$ linoleic acid as polysaturated fatty acid. Other fatty acid content of sesame oil are 0,28-0,4\% palmitic acid and 4.63$6.35 \%$ stearic acids [3].

Sesame oil is useful for health because it contains a lot of vitamin $\mathrm{E}$ and other functional components. Bioactive phytochemicals of sesame oil as anti- oxidants and anti-inflammantory. The sesame oil has tocopherols, phytosterols, and lignans that have many health functions. The health benefits of sesame oils are antioxidants, anti-atherosclerosis, anti-cancer, plasma cholesterol-lowering, and free radical inhibition effects [4]. Sesame oil also has a synergistic effect with anti-diabetic drugs, effectively providing increased hyperglycemia [5]. Sesame oil is also used as a burn reliever, controls dry scalp and kills dandruff bacteria and also has many applications in the medical and pharmaceutical fields [6]. The purpose of this journal review is to determine the physico-chemical properties, including physical properties, chemical properties, extraction, purification of sesame seed oil and its application in various food products.

\section{PHYSICAL AND CHEMICAL CHARACTERISTICS OF SESAME OIL}

\subsection{Physical Characteristics}

- Optical properties

Optical properties, namely physical characteristics to see the color and clarity of a material. Refractive Index (RI) is the time it takes for a light beam to penetrate a sample and related with structure molecular and saturation of degree oil. The standard refractive index value of sesame oil is $1.465-1.469$ at a temperature of $40^{\circ} \mathrm{C}$ [7]. In addition, the colour measurements of sesame oil has a value of about 0.99 and 1.27 tintometers in two seasons, country differences and varieties will have significantly different viscosity values (yellow-red), this is influenced by the storage period and source of sesame oil. Nair et al. [8] obtained colour results for sesame oil, namely golden yellow. Valantina et al [9] the refractive index value obtained at different extraction temperatures between $40-50 \square$ has a refractive index value at $25 \square$ of $1.4711-1.4712$ and is not significantly different.

- Viscosity

Sesame oil viscosity depends on variety, soil type, and the location where the research results show that the viscosity of the oil is not a significant difference from the same type of variety and the same conditions, 
but there are significant differences from different varieties. The viscosity of sesame oil depends on temperature, when the temperature decrease of $34 \pm 5$ ${ }^{\circ} \mathrm{C}$, the sesame oil viscosity will increase i.e between 19.24-24.47 mPa.s, while at $32^{\circ} \mathrm{C}$ the viscosity is between 18.90-26.43 mPa.s [10]. The viscosity of sesame oil in $40^{\circ} \mathrm{C}$ is $31,86 \mathrm{mPa}$.s and $100^{\circ} \mathrm{C}$ is 7,46 $\mathrm{mPa}$.s. The viscosity increase is caused by the oxidation of polymer compound [11]. Sesame oil has stability oxidative than sunflower oil but has not stable as coconut oil. This is due to the unsaturated oil and natural antioxidants (sesamin, sesamolin, and $\gamma$ tocopherol) of sesame oil that more stability and efficiently at high temperatures [8].

\section{- Smoke Point, Flash Point, Fire Point}

Smoke point depends on free fatty acids (FFA) contained in fats/oils. Flash point exhibited the temperature at which oil water vapor can ignite when exposed to a source of fire (spark) in a short time, and then the fire will go out again. The lowest temperature point when the oil/fat vapor is a fire point. Sesame oil crude processed by degumming, neutralization, and bleaching has higher values of smoke point, flash point, and fire point. The smoke point $(206.00 \pm 2.10-$ $\left.210.00 \pm 1.10^{\circ} \mathrm{C}\right)$, the flash point $(312.00 \pm 1.50-$ $\left.326.00 \pm 1.30^{\circ} \mathrm{C}\right)$ and the fire points $(335.00 \pm 0.88-$ $342.00 \pm 1.10^{\circ} \mathrm{C}$ ) [12].

\section{- Density}

Density depends on temperature, where the density of the oil will decrease at higher temperatures [13], [14]. The density of sesame oil Nair et al [8] obtained a value of $0.9216 \mathrm{~g} / \mathrm{cm}^{3}$. Ademola Olaleye [15] reported that sesame oil in the room temperature 0.990 $\pm 0.090 \mathrm{~g} / \mathrm{cm}^{3}$ and density decreases in temperature $230^{\circ} \mathrm{C}$ and $290^{\circ} \mathrm{C}$ are $0.860 \pm 0.070 \mathrm{~g} / \mathrm{cm}^{3}$ and $0.690 \pm$ $0.010 \mathrm{~g} / \mathrm{cm}^{3}$.

\subsection{Chemical Characteristics}

Sesame oil has chemical characteristic i.e proximate analysis, acid value, peroxide number, saponification number, iodine number, tocopherol content, and antioxidant capacity. Chemical characteristics of sesame oil shown in Table 1.

Table 1: Chemical characteristics of sesame oil

\begin{tabular}{|c|c|c|}
\hline Characteristics & Values & References \\
\hline Moisture content (\%) & 5.7 & \multirow{6}{*}{ [1] } \\
\hline Crude protein $(\%)$ & 20 & \\
\hline Ether / fat extract (\%) & 54 & \\
\hline Crude fiber $(\%)$ & 3.2 & \\
\hline Ash content (\%) & 3.7 & \\
\hline Total carbohydrate (\%) & 13.4 & \\
\hline Iod number $\left(\mathrm{gI}_{2} / 100 \mathrm{~g}\right)$ & $103-116$ & \multirow{4}{*}{ [17] } \\
\hline $\begin{array}{l}\text { Saponation number } \\
(\mathrm{mg} \mathrm{KOH} / \mathrm{g})\end{array}$ & 189-191 & \\
\hline $\begin{array}{l}\text { Acid Value } \\
\text { (mg KOH/g) }\end{array}$ & $0.45-0.5$ & \\
\hline $\begin{array}{l}\text { Peroxidate number } \\
\text { (Meq KOH/g) }\end{array}$ & $7.45-8$ & \\
\hline
\end{tabular}

The chemical characteristics of sesame seed oil i.e.

\section{- Proximate analysis}

Sesame oil has the highest of ether extract at $54 \%$ and the lowest on moisture, fiber, and ash content. The higher ether oil extract has potential for the oil industry.

Anilakumar et al [16], the value of fat sesame oil $43.4 \%$, meanwhile Nzikou et al., (2010) fat result of sesame oil is $54 \%$. The differences in sesame yield oil due to the variety of sesame seeds, the growth climate, the ripening stage, the harvesting time, and the extraction method [1].

- Fatty acid

Mariod et al [18] The fatty acid sesame oil are (14: 0) $0.02 \pm 0.1 \%$; (16:0) $9.76 \pm 0.3 \%$; (16: 1) $0.17 \pm$ $01 \%$; (17: 0 ) $0.1 \pm 0.1 \%$; (18: 0 ) $6.17 \pm 0.3$; (18: 1) $39.83 \pm 0.4 \%$; (18: 2) $41.43 \pm 0.2 ;(18: 3) 0.34 \pm$ $0.2 \%$; (20: 0) $0.68 \pm 0.1 \%$; (20: 1) $0.17 \pm 0.1 \%$, (22: 0) $0.19 \pm 0.1 \%$, Poly Unsaturated Fatty Acids (PUFA) $41.7 \pm 0.4 \%$; Total Saturated Fatty Acids (TSFA) $17.04 \pm 0.2 \%$; Total Unsaturated Fatty Acids (TUSFA) $82.93 \%$. Different methods of extracting oil by supercritical, subcritical techniques and conventional methods can affect differences in lipid composition and chemical characteristics, but according to Shi et al [19] showed that the difference between fatty acids and triacylglycerol was not significant. Thakur et al [6], The composition fatty acid of sesame seed oil depend on several factors including climate, soil conditions, plant maturity. The Fatty Acid value of sesame oil in Table 2.

Table 2: Fatty Acid Value and composition of Sesame Oil

\begin{tabular}{|c|c|c|c|}
\hline Fatty acid & $\begin{array}{c}\text { Chemical } \\
\text { formula }\end{array}$ & $\begin{array}{c}\text { Nzikou } \\
\text { et al [1] }\end{array}$ & Hui [2] \\
\cline { 3 - 4 } & & 8.66 & 11.8 \\
\hline Saturated : & \multicolumn{4}{|l|}{} \\
\hline Palmitic acid & $\mathrm{C}_{16} \mathrm{H}_{32} \mathrm{O}_{2}$ & 6.40 \\
\hline Stearic acid & $\mathrm{C}_{18} \mathrm{H}_{36} \mathrm{O}_{2}$ & 5.45 & 44.06 \\
\hline Unsaturated : \\
\hline Oleic acid & $\mathrm{C}_{18} \mathrm{H}_{34} \mathrm{O}_{2}$ & 38.86 & 35.56 \\
\hline Linoleic acid & $\mathrm{C}_{18} \mathrm{H}_{32} \mathrm{O}_{2}$ & 46.18 & \\
\hline
\end{tabular}

The acid value in oils and fats shows the quality as seen from the free fatty acid content. The acid value is the number of $\mathrm{KOH}$ neutralize of free fatty acids (FFA) in one gram of oil. he large acid value indicates the formation of large Free Fatty Acid (FFA) from oil hydrolysis and also indicates the quality of the fat/oil [9]. The lower the free fatty acids, the better of quality of the fat/oil [7]. Sesame oil has a low acid value which indicates that it contains less free fatty acids and reduces exposure to rancidity [20]-[22].

\section{- Saponification number}

The saponification number is the amount (mg) of $\mathrm{KOH}$ to lather 1 gram of fat or oil. The saponification number determine of molecular weight of fats/oils. 
Nair et al [8], obtained a lathering value of $191 \mathrm{mg}$ $\mathrm{KOH} / \mathrm{g}$ same with Handajani et al [23], the sampling sesame oil rates analyzed for different extraction temperatures obtained peroxide values of 186-191.

\section{- Iodine Number}

The iodine (IV) number is grams of iodine absorbed by vegetable oil, and present of unsaturated fatty acids. The higher of iodine number indicates the higher of amount unsaturated fatty acids [8].

\section{- Peroxidate number}

The peroxide number can show how rancid an oil is after storage by measuring lipid oxidation. Nzikou et al [1], the amount of sesame oil peroxides increased with temperature and storage conditions. Chakraborty et al [24], hat the value of the peroxide number increased from 5.1-42 meq / $\mathrm{Kg}$ within 45 days of storage. Peroxide values differ in location and variety of sesame oil. The amount of peroxide of the three varieties of sesame seed is between 4.8 and 5.3 meq / $\mathrm{kg}$ of oil. Different locations have peroxide values between $0.220-22.55 \mathrm{meq} / \mathrm{Kg}$ of oil [7].

\section{- Antioxidant Activity}

The antioxidant activity of sesame oil shows higher stability than other vegetable oils [25]. The content and antioxidant activity can be increased by heating the sesame seeds. This occurs due to the process of thermal degradation of the sesamolin compound or sesame lignin into sesamol [25]. The main lignins found in roasted sesame seeds are sesamin and sesamolin. Shi et al [19], sesamol value at $30 \mathrm{mg} / 100 \mathrm{~g}$, sesamin at $947 \mathrm{mg} / 100 \mathrm{~g}$, and sesamolin $173 \mathrm{mg} / 100 \mathrm{~g}$ in several sesame oil samples.

Ssesame oil has tocopherols as antioxidants that break down radical chains in membranes, lipoproteins, and food. The amount of tocopherol in sesame oil is not classified as high, only $64.74 \mathrm{mg} / 100 \mathrm{~g}$. $\alpha$ tocopherol and $\boldsymbol{\gamma}$-tocopherol are the most abundant tocopherols in sesame oil [25]. In addition, sesame oil have sterols with the ethylidene group which is also effective as antioxidants [18]. According to Shi et al [19], showed that oxygen atoms that are rich in electrons in the hydroxyl groups of stigmasterol and $\beta$ cytisterol can improve oxidation properties with their ability to donate electrons to free radicals. In addition, according to Nair et al [8] sesame oil contains natural antioxidants that give it better shelf life.

\subsection{Sensory Characteristics}

The quality of sesame oil is determined by the color of the oil, its taste, and aroma, which are unique aroma, bright color, and great taste. The quality of sesame oil depends on raw material, it showed good characteristics of oil if good raw material [26].

The drying model greatly affects the taste and aroma of the oil. The roasting model produces highquality oil (aroma and taste of sesame) [26]. Roasting sesame seeds produces a distinctive and intense taste, roasting the seeds at a temperature of $160-180^{\circ} \mathrm{C}$ has increased the volatile compounds in sesame oil, but until 1988, only a few volatiles had been identified in roasted sesame seed extracts [2]. The color of sesame oil with a comparison of different treatments, namely roasting and roasting has different colors, such as the 20 minutes roasting treatment produces a yellow oil color than the oil produced by the oven for 5 minutes. This occurs because the browning reaction is not too thick and the heating process is different. The orange-yellow color in the oil indicates the presence of dissolved carotene pigments in oil or fat [23].

\section{EXTRACTION AND PURIFICATION}

The extraction methods for the sesame oil are rendering (dry rendering and wet rendering), mechanical pressing, and solvent extraction (soxhlet and maceration). Rendering is the extraction of fats and oils from materials containing fats and oils with high water content, in principle, by breaking down the heat to coagulate proteins in the cell walls of the material and break down the cell walls so that they are easily penetrated by the fats and oils in them. Mechanical pressing is an extraction method to separate materials that have high levels of fat and oil (30-70\%), especially those from seeds. Solvent extraction is used for materials that have low levels of fat and oil. The extraction method is by Soxhlet (extraction using an organic solvent that is carried out repeatedly) and maceration (extracting the material by soaking in a solvent) [27].

Chakraborty et al [24], The method of extraction of sesame oil by Soxhlet extractor EX5 / 55/100 100 $\mathrm{ml}$ QuickFit Glass, England with several pretreatments and using different organic solvents including n-hexane, ethanol, carbon tetrachloride, and petroleum ether. The highest extract off-white sesame seed yield with n-hexane solvent at $46 \%$ and the lower yield with CCI4 solvent at $41 \%$. The results obtained from the physical properties of sesame oil are iodine value 111-112 g / 100gram oil, saponification value 189-190 mgKOH / g, acid value 0.68-0.78 mg KOH / $\mathrm{g}$, and peroxide value $4.8-5.3 \mathrm{meq} / \mathrm{kg}$ of oil.

Romadhona et al [28], The extraction of sesame using the pressing method. Sesame seeds are first heated and then pressed with a compression machine with a pressure of $350 \mathrm{kN}$ at a temperature of $\pm 85^{\circ} \mathrm{C}$. Drying or heating is done by the roasting, oven, and steaming, with time ranges are 5-20 minutes with a time difference of 5 minutes. The results obtained are that the yield is getting bigger with the duration of heating. The heat generated will damage the anatomical structure of the cells in sesame seeds and make their viscosity decrease.

Crude edible oils are sometimes being processed to refined oil by subjecting it to degumming, neutralization, bleaching and deodourization in order to enhance its edibility qualities. Arawande and Alademeyin [12], degumming of crude sesame oil aims to remove gums and phospholipids by phosphoric acid. The degumming sesame oil is carried 
out by a neutralization process using a sodium hydroxide solution. The lower layers washed with water to remove caustic soda and water-soluble gum in the oil. The next process is bleaching of sesame oil with bleaching earth and heated to $110 \mathrm{oC}$. The processing of the crude sesame oil to bleached oil improves the qualities of the oil.

\section{THE APPLICATION OF SESAME OIL IN FOOD PRODUCTS}

Sesame oil has been widely used in everyday life. Generally, sesame oil is used as cooking and salad oil. Sesame oil has a slightly nutty taste, making it excellent for stir-fried dishes. In addition, the sesame seed oil can be used directly without refining in natural salad [29].

Sesame oil is also used as an ingredient in other products such as mayonnaise [30], oleogels [31], and cocoa cream fat [32]. The application of sesame oil in food products can be seen in Table 3 .

\subsection{Mayonnaise}

Mayonnaise is an emulsion food made from vegetable oil, vinegar, lemon, egg yolk, salt, sugar, mustard, and several natural spices [30]. Mayonnaise has a main component, namely vegetable oil up to 50$75 \%$ [33]. Several studies have used sesame oil as an additive in making Mayonnaise which will affect the physical and sensory properties of the mayonnaise product. This because of the composition of fatty acids i.e polyunsaturated fatty acids (PUFAs), Monounsaturated fat (MUFAs), and saturated fatty acids (SFAs) on a sesame oil. Rahmati et al [34], Making mayonnaise by adding sesame oil to form an emulsion. The results obtained, mayonnaise with the addition of sesame oil (MUFA $31.25 \pm 0.33 \%$ and PUFA $52.59 \pm 0.47 \%$ ) were less accepted by consumers. [33] that sesame oil has the highest MUFA value of $41.40 \%$ and a relatively high PUFA, which is $43.50 \%$, but it is still higher in PUFA in sunflower oil and soybean oil, $\mathrm{pH}$ characteristics do not really affect the fatty acid composition. While viscosity is very influential, mayonnaise with a mixture of sesame oil has the lowest viscosity due to the high MUFA composition.

\subsection{Oleogel}

Oleogel is a composition of organogelators such as solid mixtures or polymer gelators. Oleogels is good for health because can alternative to avoid saturated fatty acids [31], [35]. Sesame oil is applied as a way of making oleogel with a PW (Propolis Wax) or BW (BeeWax) organogelator. Beewax is a wax produced by bees which contains several chemical compounds (ester, diester and trimester) [36]. Mogtadaei et al [37], while propolis wax consists of components of renin, pollen, wax, essential oils and other organic compounds produced by bees.

Fayaz et al [31], showed that the PW-organogel crystal form is like a needle, the structure is the same as micro beeswax and cannot be constructed by any type of vegetable oil. The morphology of oleogel crystals was informed using the XRD pattern that the results obtained were not other factors and the results were similar to one another, because the XRD pattern was compared to oleogel of several vegetable oils. The crystalline form present in the PW oleogel with sesame oil is the $\beta^{\prime}$-form in the fine triglyceride crystals. The thermal character or the melting peak is at a temperature of $49.7 \square$, the type of oil does not affect thermally [38].

Mogtadaei at al [37], compared BW oleogel with animal fats that the acid value and peroxide value were lower than animal fat. BW concentration and cooling rate affect the color produced by $\mathrm{BW}$-oleogel which is brighter and more yellow. The higher the BW concentration and the lower the cooling temperature (4 $\square$ ) will make the BW-oleogel color lighter, while the higher the $\mathrm{BW}$ concentration and the higher the cooling temperature $(25 \square)$ will make the color more yellow.

Melting point BW-oleogel compared to animal fat has a higher value of $48.05 \square-52.20 \square$ even though oleogel has higher unsaturated fatty acids than animal fat. The texture characteristic of $\mathrm{BW}$ oleogel has a lower hardness value than animal fat. This is because of the amount of unsaturated fatty acids and cooling temperature. The more unsaturated fatty acids, the more flexible the texture and the lower the cooling temperature, the higher the hardness level [37].

Fayaz et al [31], crystal shape in oleogels is influenced by the cooling temperature, at $25 \square$ it looks clustered and the pores are bigger, while at $4 \square$ the structure is tighter and the pores are smaller. substitution animal fat with BW-oleogel in the raw burger has a reduction of characteristic hardness, chewiness, and brightness. Incorporation of PWoleogel into beef burgers can reduce cooking loss and fat absorption.

\subsection{Cocoa Cream Fat}

Cocoa Cream is a high sugar and vegetable fat product. Its composition is powdered sugar, powdered cocoa, powdered milk, vegetable fat, and others [32]. Partial and total substitution of vegetable oils with sesame oil was to determine rheological characteristics, crystallization, physical properties, and shelf life of Spreadable Cocoa Cream products. The formulation containing more sesame oil would reduce the crystallization rate. The rheological properties did not differ significantly, but a significant increase of viscosity and yield decrease of stress for the same oil type.

Table 3: The Application of Sesame Oil in Food Products

\begin{tabular}{|c|l|c|}
\hline $\begin{array}{c}\text { Products } \\
\text { Application }\end{array}$ & \multicolumn{1}{|c|}{$\begin{array}{l}\text { Product } \\
\text { Characteristics }\end{array}$} & Reference \\
\hline Mayonnaise & $-\begin{array}{l}\text { Taste has a lower } \\
\text { value than other } \\
\text { samples }\end{array}$ & $-\quad[30]$ \\
& $\begin{array}{l}\text { Oxidation } \\
\text { stability } \gg>\end{array}$ & \\
\hline
\end{tabular}




\begin{tabular}{|c|c|c|}
\hline & 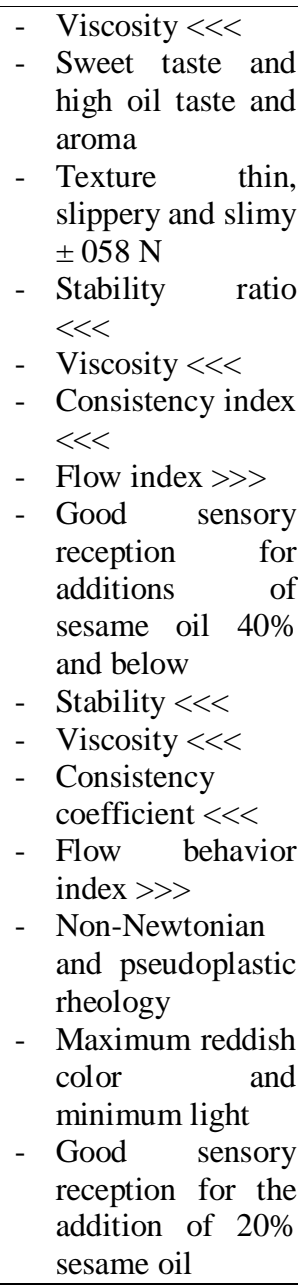 & - [39] \\
\hline Oleogel & $\begin{array}{ll}\text { - } & \text { Needle-shaped } \\
& \text { crystal }\left(\beta^{\prime}\right) \\
\text { - } & \text { Melting point } \\
& 49.7 \square \\
\text { - } & \text { Melting point } \\
& 48,05 \square-52,20 \square \\
\end{array}$ & $\begin{array}{ll}- & {[31]} \\
- & {[37]}\end{array}$ \\
\hline $\begin{array}{c}\text { Cocoa Cream } \\
\text { Fat }\end{array}$ & $\begin{array}{ll}\text { - } & \text { Decrease } \\
& \text { crystallization } \\
\text { - } & \text { Increase viscosity } \\
\text { - } & \text { Lowering stress } \\
& \text { yield } \\
\end{array}$ & - [32] \\
\hline $\begin{array}{l}\text { Structured } \\
\text { lipids }\end{array}$ & $\begin{array}{l}\text { Structured lipid } \\
\text { could be used for } \\
\text { healthy fat-based } \\
\text { products }\end{array}$ & - [41] \\
\hline $\begin{array}{c}\text { Nutraceutical } \\
\text { products }\end{array}$ & 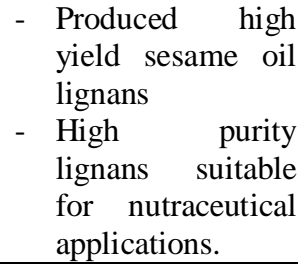 & - [42] \\
\hline
\end{tabular}

\section{CONCLUSION}

Sesame oil highest of fat extracts that potential for oil Industry. Physical and chemical characteristic of sesame oil can modify to other products that it can give health potential. The process extraction and purification of sesame oil can improve the qualities of the oil and develop in other products. Mayonnaise, oleogels, and cocoa cream fat using sesame oil showed no significant difference in the physicochemical and sensory characteristics of these products.

\section{ACKNOWLEDGEMENTS}

The authors would like to thank you for the Rector of Universitas Padjadjaran and the Ministry of Education and Culture of the Republic of Indonesia for all support provided.

\section{REFERENCES}

1. J. M. Nzikou et al., "Characterization of seeds and oil of sesame (Sesamum indicum L.) and the kinetics of degradation of the oil during heating," Res. J. Appl. Sci. Eng. Technol., vol. 2, no. 3, pp. 227-232, 2010.

2. Y. . Hui, Handbook of Fruit and Vegetable Flavors. Canada: A John Wiley \& Sons, INC Publication, 2010.

3. H. Osman, I. Shigidi, and A. Arabi, "Multiple modeling techniques for assessing sesame oil extraction under various operating conditions and solvents," Foods, vol. 8, no. 4, 2019, doi: 10.3390/foods 8040142 .

4. D. Sankar, A. Ali, G. Sambandam, and R. Rao, "Sesame oil exhibits synergistic effect with antidiabetic medication in patients with type 2 diabetes mellitus," Clin. Nutr., vol. 30, no. 3, pp. 351-358, 2011, doi: 10.1016/j.clnu.2010.11.005.

5. M. Takahashi et al., "Determination and purification of sesamin and sesamolin in sesame seed oil unsaponified matter using reversedphase liquid chromatography coupled with photodiode array and tandem mass spectrometry and high-speed countercurrent chromatography," J. Sep. Sci., vol. 39, no. 20, pp. 3898-3905, 2016, doi: 10.1002/jssc.201600723.

6. V. Thakur, S. Paroha, and R. Prakash Mishra, "Chemical Characterization and Fatty Acid Composition of Different Sesame Verities," Int. J. Curr. Microbiol. Appl. Sci., vol. 6, no. 12, pp. 1936-1943, 2017, doi: 10.20546/ijcmas.2017.612.221.

7. Y. M. A. Idris, S. A. Hassan, and A. A. Mariod, "Physicochemical characteristics and aflatoxin levels in two types of sudanese sesame oil," JAOCS, J. Am. Oil Chem. Soc., vol. 90, no. 7, pp. 989-998, 2013, doi: 10.1007/s11746-013-22410 .

8. S. S. Nair, K. P. Nair, and P. K. Rajendrakumar, "Evaluation of physicochemical, thermal and tribological properties of sesame oil (Sesamum indicum L.): A potential agricultural crop base stock for eco-friendly industrial lubricants," Int. J. Agric. Resour. Gov. Ecol., vol. 13, no. 1, pp. 77-90, 2017, doi: 10.1504/IJARGE.2017.084037. 
9. S. R. Valantina, V. Mukesh Kumar, and T. Devasena, "Selected rheological characteristics and physicochemical properties of vegetable oil affected by heating," Int. J. Food Prop., vol. 19, no. $\quad 8$, pp. 1852-1862, 2015, doi: 10.1080/10942912.2015.1024849.

10. M. K. S. El Khier, K. E. A. Ishag, and A. E. A. Yagoub, "Chemical composition and oil characteristics of sesame seed cultivars grown in Sudan," Res. J. Agric. Biol. Sci., vol. 4, no. 6, pp. 761-766, 2008.

11. J. K. Mannekote and S. V. Kailas, "The effect of oxidation on the tribological performance of few vegetable oils," J. Mater. Res. Technol., vol. 1, no. 2, pp. 91-95, 2012, doi: 10.1016/S22387854(12)70017-0.

12. J. O. Arawande and J. O. Alademeyin, "Influence of Processing on Some Quality Identities of Crude Sesame ( Sesamum indicum ) Seed Oil," Int. J. Food Nutr. Saf., vol. 9, no. 1, pp. 59-74, 2018.

13. H. Noureddini, B. C. Teoh, and L. Davis Clements, "Viscosities of vegetable oils and fatty acids," J. Am. Oil Chem. Soc., vol. 69, no. 12, pp. 1189-1191, 1992, doi: 10.1007/BF02637678.

14. S. N. Sahasrabudhe, V. Rodriguez-Martinez, M. O’Meara, and B. E. Farkas, "Density, viscosity, and surface tension of five vegetable oils at elevated temperatures: Measurement and modeling," Int. J. Food Prop., vol. 20, no. 00, pp. 1965-1981, 2017, doi: 10.1080/10942912.2017.1360905.

15. A. Ademola Olaleye, "Effects of Temperature Change on the Physico-Chemical Properties of Sesame Seed Oil," Sci. J. Anal. Chem., vol. 7, no. $1, \quad$ p. $13, \quad 2019, \quad$ doi: 10.11648/j.sjac.20190701.12.

16. K. R. Anilakumar, A. Pal, F. Khanum, and A. S. Bawa, "Nutritional, medicinal and industrial uses of sesame (sesamum indicum L.) seeds - An overview," Agric. Conspec. Sci., vol. 75, no. 4, pp. 159-168, 2010.

17. M. Mohammed and Z. Hamza, "Physicochemical Properties of Oil Extracts from Sesamum Indicum L. Seeds Grown in Jigawa State - Nigeria," J. Appl. Sci. Environ. Manag., vol. 12, no. 2, pp. 99-101, 2010, doi: 10.4314/jasem.v12i2.55542.

18. A. Mariod, B. Matthäus, and I. H. Hussein, "Fatty acids, tocopherols and sterols of Cephalocroton cordofanus in comparison with sesame, cotton, and groundnut oils," JAOCS, J. Am. Oil Chem. Soc., vol. 88, no. 9, pp. 12971303, 2011, doi: 10.1007/s11746-011-1796-x.

19. L. K. Shi, L. Zheng, R. J. Liu, M. Chang, Q. Z. Jin, and X. G. Wang, "Chemical Characterization, Oxidative Stability, and In Vitro Antioxidant Capacity of Sesame Oils Extracted by Supercritical and Subcritical Techniques and Conventional Methods: A Comparative Study Using Chemometrics," Eur. J. Lipid Sci. Technol., vol. 120, no. 2, 2018, doi: 10.1002/ejlt.201700326.

20. I. . Roger, A.B., Rebecca, R.A., Georges, A., Mathias, "Chemical characterization of oil form germinated nuts of several coconut cultivars (Cocos nuciferh L.)," Eur. J. Sci. Res., vol. 391, pp. 514-522, 2010.

21. Elizabeth Naomi Anderson-Foster, "Physicochemical properties of Blighia sapida (ackee) oil extract and its potential application as emulsion base," African J. Pharm. Pharmacol., vol. 6, no. 3, 2012, doi: 10.5897/ajpp11.696.

22. J. E. Asuquo, A. C. I. Anusiem, and E. E. Etim, "Effect of $\mathrm{pH}$ on the Adsorption of Metallic Soaps of Shea Butter Oil onto Hematite in Aqueous Medium," Int. J. Mod. Chem., vol. 2, no. 2, pp. 74-83, 2012.

23. S. Handajani, G. J. Manuhara, R. Baskara, and K. Anandito, "Effect of Extraction Temperature on Physical, Chemical and Sensory Characteristics of Virgin Sesame Oil (Sesamum Indicum L.)," Agritech, vol. 30, no. 2, pp. 116122, 2010, doi: 10.22146/agritech.9682.

24. D. Chakraborty, J. Das, P. K. Das, S. C. Bhattacharjee, and S. Das, "Evaluation of the parameters affecting the extraction of sesame oil from sesame (Sesamum indicum L.) seed using soxhlet apparatus," Int. Food Res. J., vol. 24, no. 2, pp. 691-695, 2017.

25. Y. Wan, H. Li, G. Fu, X. Chen, F. Chen, and M. $\mathrm{Xie}$ "The relationship of antioxidant components and antioxidant activity of sesame seed oil," J. Sci. Food Agric., vol. 95, no. 13, pp. 2571-2578, 2015, doi: 10.1002/jsfa.7035.

26. B. LS, P. I. R, and N. M.P, "Test Production Model on Varieties to Produce Quality Sesame Oil," Int. J. Adv. Eng. Res. Sci., vol. 6, no. 1, pp. 25-29, 2019, doi: 10.22161/ijaers.6.1.4.

27. P. E. Dim, "Extraction and characterization of oil from sesame seed," Res. J. Pharm. Biol. Chem. Sci., vol. 4, no. 2, pp. 752-757, 2013.

28. S. Romadhona, M. Lutfi, and R. Yulianingsih, "Study Methods and Prolonged Heating in the Extraction of Sesame Seed Oil (Sesamum indicum L)," J. Bioproses Komod. Trop., vol. 3, no. 1, pp. 50-57, 2015.

29. R. Akinoso, J. C. Igbeka, and O. T.M.A, "Process Optimization of Oil Expression from Sesame Seed (Sesamum indicum Linn.)," Agric. Eng. Int. CIGR Ejournal, vol. VIII, pp. 1-7, 2006.

30. Ebtihal Y. Khojah and Rokayya A. Sami, "Fatty Acids Composition and Oxidative Stability of Peanut and Sesame Oils with the Sensory Evaluation of Mayonnaise Prepared by Different Oils," Assiut J. Agric. Sci., 2016, doi: 10.21608/ajas.2016.2759.

31. G. Fayaz, S. A. H. Goli, and M. Kadivar, "A Novel Propolis Wax-Based Organogel: Effect of Oil Type on Its Formation, Crystal Structure and Thermal Properties," JAOCS, J. Am. Oil Chem. Soc., vol. 94, no. 1, pp. 47-55, 2017, doi: 10.1007/s11746-016-2915-5. 
32. I. Lončarević et al., "Influence of Rapeseed and Sesame Oil on Crystallization and Rheological Properties of Cocoa Cream Fat Phase and Quality of Final Product," J. Texture Stud., vol. 47, no. 5, pp. 432-442, 2016, doi: 10.1111/jtxs.12179.

33. H. N. Lioe, N. Andarwulan, D. Rahmawati, F. T. Pertanian, E. A. Food, and A. Sciences, "Physicochemical and Sensory Mayonnaise Characteristics on Different Fatty Acid Compositions from Different Vegetable Oil Usage," vol. 5, no. 1, pp. 1-9, 2018.

34. K. Rahmati, M. Mazaheri Tehrani, and K. Daneshvar, "Soy milk as an emulsifier in mayonnaise: physico-chemical, stability and sensory evaluation," J. Food Sci. Technol., vol. 51, no. 11, pp. 3341-3347, 2014, doi: 10.1007/s13197-012-0806-9.

35. E. Subroto, "Monoacylglycerols and diacylglycerols for fat-based food products: a review," Food Res., vol. 4, no. 4, pp. 932-943, 2020, doi: 10.26656/fr.2017.4(4).398.

36. F. Fratini, G. Cilia, B. Turchi, and A. Felicioli, "Beeswax: A minireview of its antimicrobial activity and its application in medicine," Asian Pac. J. Trop. Med., vol. 9, no. 9, pp. 839-843, 2016, doi: 10.1016/j.apjtm.2016.07.003.

37. M. Moghtadaei, N. Soltanizadeh, and S. A. H. Goli, "Production of sesame oil oleogels based on beeswax and application as partial substitutes of animal fat in beef burger," Food Res. Int., vol.
108, no. September 2017, pp. 368-377, 2018, doi: 10.1016/j.foodres.2018.03.051.

38. L. S. K. Dassanayake, D. R. Kodali, S. Ueno, and K. Sato, "Crystallization kinetics of organogels prepared by rice bran wax and vegetable oils," J. Oleo Sci., vol. 61, no. 1, pp. 1-9, 2012, doi: 10.5650/jos.61.1.

39. R. Chetana, K. P. Bhavana, R. Babylatha, V. Geetha, and G. Suresh Kumar, "Studies on eggless mayonnaise from rice bran and sesame oils," J. Food Sci. Technol., vol. 56, no. 6, pp. 3117-3125, 2019, doi: 10.1007/s13197-01903819-1.

40. R. Pazhvand and M. Khavarpour, "Rheological, Physical and Sensory Properties of Mayonnaise Formulated With Sesame Oil," J. Food Biosci. Technol., vol. 9, no. 1, pp. 35-44, 2019.

41. S. Sivakanthan, A. P. Jayasooriya, and T. Madhujith, "Optimization of the production of structured lipid by enzymatic interesterification from coconut (Cocos nucifera) oil and sesame (Sesamum indicum) oil using Response Surface Methodology," $L W T$, vol. 101, pp. 723-730, 2019, doi: https://doi.org/10.1016/j.lwt.2018.11.085.

42. M. V Reshma et al., "Extraction, separation and characterisation of sesame oil lignan for nutraceutical applications," Food Chem., vol. 120, no. 4, pp. 1041-1046, 2010, doi: https://doi.org/10.1016/j.foodchem.2009.11.047. 